\title{
RNA Sequencing Analysis Reveals Divergent Adaptive Response to Hypo- and Hyper-Salinity in Greater Amberjack (Seriola dumerili) Juveniles
}

\author{
Yuhao Peng ${ }^{1,+}{ }^{\dagger}$ Hongjuan Shi ${ }^{1,+}{ }^{+}$, Yuqi Liu ${ }^{1}$, Yang Huang ${ }^{1}$, Renchi Zheng ${ }^{1}$, Dongneng Jiang ${ }^{1}$, Mouyan Jiang ${ }^{1}$, \\ Chunhua Zhu ${ }^{1,2}$ and Guangli $\mathrm{Li}^{1, *(1)}$
}

1 Guangdong Research Center on Reproductive Control and Breeding Technology of Indigenous Valuable Fish Species, Guangdong Provincial Engineering Laboratory for Mariculture Organism Breeding, Guangdong Provincial Key Laboratory of Pathogenic Biology and Epidemiology for Aquatic Economic Animals, Fisheries College, Guangdong Ocean University, Zhanjiang 524088, China; pengyuhaopyh@163.com (Y.P.); shihj@gdou.edu.cn (H.S.); 11112012021@163.com (Y.L.); zjouhy@126.com (Y.H.); zhengrenchi1@stu.gdou.edu.cn (R.Z.); jdn1987@163.com (D.J.); jiangmouyan@gdou.edu.cn (M.J.); zhu860025@163.com (C.Z.)

2 Southern Marine Science and Engineering Guangdong Laboratory, Zhanjiang 524025, China

* Correspondence: ligl@gdou.edu.cn

+ These authors contributed equally to this work.

Citation: Peng, Y.; Shi, H.; Liu, Y.; Huang, Y.; Zheng, R.; Jiang, D.; Jiang, M.; Zhu, C.; Li, G. RNA Sequencing Analysis Reveals Divergent Adaptive Response to Hypo- and Hyper-Salinity in Greater Amberjack (Seriola dumerili) Juveniles. Animals 2022, 12, 327. https://doi.org/ $10.3390 /$ ani12030327

Academic Editors: Ioannis A. Giantsis, Costas Batargias and Konstantinos Feidantsis

Received: 30 December 2021

Accepted: 24 January 2022

Published: 29 January 2022

Publisher's Note: MDPI stays neutral with regard to jurisdictional claims in published maps and institutional affiliations.

Copyright: (C) 2022 by the authors. Licensee MDPI, Basel, Switzerland. This article is an open access article distributed under the terms and conditions of the Creative Commons Attribution (CC BY) license (https:// creativecommons.org/licenses/by/ $4.0 /)$.
Simple Summary: The gill tanscriptomes of greater amberjack (Seriola dumerili) reared under different salinity stress were analyzed. The regulatory networks of salinity-related pathways were explored through Kyoto Encyclopedia of Gene and Genome (KEGG) pathway enrichment and bioinformatics analyses. This will be of great value in understanding the molecular basis of salinity adaptation in greater amberjack.

Abstract: Salinity significantly affects physiological and metabolic activities, breeding, development, survival, and growth of marine fish. The greater amberjack (Seriola dumerili) is a fast-growing species that has immensely contributed to global aquaculture diversification. However, the tolerance, adaptation, and molecular responses of greater amberjack to salinity are unclear. This study reared greater amberjack juveniles under different salinity stresses (40,30, 20, and $10 \mathrm{ppt})$ for 30 days to assess their tolerance, adaptation, and molecular responses to salinity. RNA sequencing analysis of gill tissue was used to identify genes and biological processes involved in greater amberjack response to salinity stress at 40,30, and 20 ppt. Eighteen differentially expressed genes (DEGs) (nine upregulated and nine downregulated) were identified in the $40 \mathrm{vs.} 30 \mathrm{ppt}$ group. Moreover, 417 DEGs (205 up-regulated and 212 down-regulated) were identified in the 20 vs. 30 ppt group. qPCR and transcriptomic analysis indicated that salinity stress affected the expression of genes involved in steroid biosynthesis (ebp, sqle, lss, dhcr7, dhcr24, and cyp51a1), lipid metabolism (msmo1, $n s d h l, o g d h$, and edar), ion transporters (slc25a48, slc37a4, slc44a4, and apq4), and immune response (wnt4 and tlr5). Furthermore, KEGG pathway enrichment analysis showed that the DEGs were enriched in steroid biosynthesis, lipids metabolism, cytokine-cytokine receptor interaction, tryptophan metabolism, and insulin signaling pathway. Therefore, this study provides insights into the molecular mechanisms of marine fish adaptation to salinity.

Keywords: transcriptome; carangidae; aquaculture; differential gene expression

\section{Introduction}

Marine environmental factors, such as salinity, low $\mathrm{O}_{2}$ concentration, temperature, and $\mathrm{pH}$ value, influence the physiological and biological status of marine animals [1]. For instance, environmental stresses activate the sympathetic nervous system [2], the release of adrenaline and noradrenaline [3], and the hypothalamic-pituitary-interrenal axis in fish [4], 
thus causing the release of the steroid glucocorticoid hormones and other hormones for adaptation [5]. Although salinity enhances optimum fish growth, it can influence growth rate, immunity, antioxidant capacity, and lipid metabolism in fish [6,7]. For instance, salinity stress induces more active energy metabolism, including lipid metabolism and glycogen metabolism [8]. Salt stress environments trigger various metabolic changes in fish, thus enhancing fish adaptation to salinity $[9,10]$. Moreover, osmolality and water balance are energy-demanding processes maintained through osmoregulatory mechanisms, and they often alter survival, growth, and other physiological processes [11-13].

Osmotic stress responses associated with salinity changes activate molecular and physiological adaptations, such as variations in cell proliferation and differentiation of osmoregulatory organs [12], modulation of the expression and activity of ATPases [14], secondary activation of ion transporters [15], and structural proteins [16]. The osmoregulatory organs of fish include the gill, kidney, and digestive tracts. However, the gill plays the most crucial role because it has a large surface area and direct contact with the external environment $[17,18]$. Blood and water in gills are separated by just a few micrometers, thus facilitating the exchange of gases and allowing gill tissue to be exposed to environmental variation and pollutants [19]. Moreover, gills can balance the ion concentration in blood and acid base in freshwater and seawater-adapted fish [20-22]. Salinity changes can cause many lesions in gills, such as vascular congestion [8], lamellar fusion, mucosal cell and gill filament epithelium hyperplasia, loss of the structural integrity of pillar cells, and an increased number of chloride cells [23,24]. These lesions can change the crucial functions of gills and alter their morphological structure [19].

Some researchers have focused on the influence of salinity on the osmotic regulation of gills to investigate ionic and osmotic regulation in fish [9]. Furthermore, many studies have assessed the transcript expression profiles of teleosts, such as marbled eel (Anguilla marmorata) [25,26], spotted sea bass (Lateolabrax maculatus) [27], half-smooth tongue sole (Cynoglossus semilaevis) [28], Nile tilapia (Oreochromis niloticus) [15,29], silvery pomfret (Pampus argenteus) [30], Mozambique tilapia (Oreochromis mossambicus) [6], and Atlantic salmon (Salmo salar), after exposure to salinity changes [17]. As a result, some significantly differentially expressed genes and pathways related to salinity changes have been identified [31]. For instance, many classical ion transporters, including channels for amino acids [32], water [33], small solutes [34], calcium ions [35], sodium [36], chloride [37], and potassium [38], such as SLC (solute transport protein) families [39], AQP (aquaporin) families [40], NPY (neuropeptide Y receptor) families [41], and TRP (transient receptor potential) families are differentially expressed in the gills of teleosts under salinity changes [42]. Furthermore, researchers have also focused on pathways, including steroid biosynthesis, immune response, energy metabolism, apoptosis, cytokine-cytokine receptor interaction, and toll-like receptor signaling pathways [43].

The greater amberjack Seriola dumerili is a large, fast-growing species in the aquaculture industry worldwide with high commercial value $[27,28]$. Many researchers have assessed the factors limiting reproduction [44], ectoparasites [45], and weaning diets of greater amberjack [46]. However, no research has identified the optimum and limiting environmental factors for greater amberjack juveniles in captivity. This study explored the influence of different salinities on the gill transcriptome and gene expression of greater amberjack juveniles to identify and assess the genes with potential roles in salinity adaptation using RNA sequencing. Therefore, this study can provide a basis for understanding the physiology of greater amberjack and practical guidance for its commercial aquaculture production.

\section{Materials and Methods}

\subsection{Ethics Statement}

The experiments were conducted following the guidelines and regulations of the Animal Research and Ethics Committee of Guangdong Ocean University (NIH Pub. No. 85-23, revised 1996) and China's laws and regulations on biological research. This study did not include any endangered or protected species. 


\subsection{Experimental Fish, Salinity Development, and Tissue Collection}

A total of 80 greater amberjack juveniles (body length, $8.33 \pm 0.45 \mathrm{~cm}$ and body weight, $6.38 \pm 1.33 \mathrm{~g}$ ) were used in this study. Before experiments, the greater amberjack juveniles were reared in tanks at $22 \pm 1.0^{\circ} \mathrm{C}$ in Donghai Island (Zhanjiang, Guangdong, China). They were randomly divided into four cylindrical $1000 \mathrm{~L}$ tanks $(20$ individuals per tank) at various salinities: 40,30, 20, and $10 \mathrm{ppt}$ (parts per thousand) groups. The salinity levels in the experiment were selected based on the previous salinity adaption study of greater amberjack larvals [47] and our unpublished data of juveniles. The fish in the control group were reared in natural seawater with a salinity of $30 \mathrm{ppt}$. The 40, 20, and 10 ppt groups were regulated using a commercial seawater salty crystal and aerated tap water. The fish were fed on commercial float bait twice a day at 9:00 and 19:00 for 30 days. Six fish were randomly selected from each group on 0,15 , and 30 days in our study, which was based on studies of other fishes, such as Asian seabass (Lates calcarifer, Bloch, 1790) [48], catfish (Lophiosilurus alexandri) [24], and cobia (Rachycentron canadum), under different salinity stress levels [31]. Unfortunately, the fish in the $10 \mathrm{ppt}$ group were all dead within 10 days. The fish were then anesthetized using $100 \mathrm{mg} / \mathrm{L}$ tricaine methane sulfonate (MS 222; Sigma-Aldrich, St. Louis, MO, USA) and dissected. The gill tissues were immediately collected in centrifuge tubes containing $1 \mathrm{~mL}$ RNA stabilization reagent overnight, then stored at $-80^{\circ} \mathrm{C}$ for RNA extraction, sequencing, and gene expression analysis. The RNA of gill samples after 30 days were used for transcriptomic analysis, all gill samples after 15 and 30 days were used for qPCR verification.

\subsection{Total RNA Extraction, Library Construction, and Illumina Sequencing}

Trizol reagent (Invitrogen, Carlsbad, CA, USA) was used to extract total RNA from the gill tissues, following the manufacturer's instructions. As previously described, the cleavage of gill tissue samples, RNA extraction, RNA purity, degradation, and contamination examinations were performed [49]. An Agilent 2100 bioanalyzer (Agilent Technologies, Palo Alto, CA, USA) was used to detect RNA integrity. Total RNA with an RNA integrity number (RIN) score $>7$ was used for sequencing.

TrueSeq RNA Sample Prep Kit (Illumina, San Diego, CA, USA) was used to obtain complementary DNA (cDNA) libraries from gill tissue, following the manufacturer's instructions. Then, $3 \mu \mathrm{L}$ of USER Enzyme (NEB, New England Biolabs, Palo Alto, CA, USA) was used with size-selected, adaptor-ligated cDNA at $37^{\circ} \mathrm{C}$ for $15 \mathrm{~min}$, followed by 5 min at $95^{\circ} \mathrm{C}$ before PCR. PCR was performed using Phusion High-Fidelity DNA polymerase, universal PCR primers, and Index (X) Primer. The AMPure XP system was used to purify the PCR products. An Agilent Bioanalyzer 2100 system was used to assess the library quality. A cBot Cluster Generation System was used to cluster the index-coded samples via the TruSeq PE Cluster Kit v4-cBot-HS (Illumia, San Diego, CA, USA), following the manufacturer's instructions. The library preparations were then sequenced on a HiSeq $\mathrm{X}$-ten platform to generate the paired-end reads (150 bp).

\subsection{Transcriptome Assembly and Functional Gene Annotation}

The assembled Seriola dumerili genome (deposited in the DNA Data Bank of Japan (DDBJ) under accession numbers BDQW01000001-BDQW01034655 (Biosample ID: SAMD00083043_sdu_WGS.acclist.zip)) was used as a reference database for mapping reads [50]. The Illumina high-throughput sequencing platform was used to sequence the cDNA library, generating raw reads/data. The raw reads/data were filtered, then the adapter sequence and ploy-N (unable to determine base information) and low-quality (reads with $<50 \%$ bases of quality value) reads were removed to obtain high-quality clean reads/data. Raw data and clean data were saved in FASTQ format. The Q20, Q30, GCcontent, and sequence duplication levels of the clean data were measured. All the subsequent analyses were based on high-quality clean data.

BLASTx (version 2.2.26) (https://blast.ncbi.nlm.nih.gov/Blast.cgi, accessed on 29 December 2021) (E-value threshold, $1 \times \mathrm{e}^{-5}$ ) was used to annotate the gene function via 
the NR (https: / / www.ncbi.nlm.nih.gov / refseq / , accessed on 29 December 2021), SwissProt (protein) (https:/ / www.uniprot.org/;\%20version\%2020140317, accessed on 29 December 2021), KEGG (https: / / www.genome.jp/kegg/, accessed on 29 December 2021), COG (https:/ / www.ncbi.nlm.nih.gov/research/cog/, accessed on 29 December 2021), and KOG (https: / / www.ncbi.nlm.nih.gov/research/cog-project/, accessed on 29 December 2021) databases, using the default setting. The clean library sequencing data were submitted to the National Center for Biotechnology Information (NCBI) Sequence Read Archive (SRA) (Bioproject number: PRJNA783747 (SRR17041711-SRR17041719)).

\subsection{Analysis of Differential Expressed Genes (DEGs) Analysis}

The greater amberjack gene expression levels were detected using the fragments per kilobase per million (FPKM) method. The DEGs in 20 vs. 30 ppt and 30 vs. 40 ppt groups were identified using the DESeq2 R package (version 1.16.1). DESeq2 was used to determine differential expression in digital gene expression data based on the negative binomial distribution model. Genes with a fold change $\geq 2$ and a false discovery rate $($ FDR $)<0.05$ were considered DEGs. A KEGG pathway analysis was conducted, and DEGs with $p<0.05$ were considered statistically significant [31]. In Donghai island, 30 ppt was the natural salinity of seawater. The DEGs in both 20 vs. 30 ppt and 30 vs. 40 ppt were identified and screened in order to clarify the effects of hypo-salinity and hyper-salinity seawater environments on gills of greater amberjack compared with the natural salinity.

\subsection{Quantitative Real-Time PCR (QPCR) Validation}

The expression patterns of DEGs in the RNA sequencing analysis were validated using qPCR. Sample collection, RNA extraction, and reverse transcription were performed as previously described [51]. RNA samples were obtained from the 20, 30, and $40 \mathrm{ppt}$ groups. Each group had three replicates. The DEGs primers were designed using Primer5 software based on the assembled transcripts. A light CyclerTM96 (Roche, Indianapolis, IN, USA) was used for qPCR analysis, following the protocol of SYBR Green Real-Time PCR Master Mix (Takara, Tokyo, Japan). $\beta$-actin was used as a reference gene to normalize the expression levels [52-54]. The relative abundance of DEG mRNA transcripts was evaluated using the $2^{-\triangle \triangle \mathrm{Ct}}$ method. The primer sequences for qPCR are shown in Table S1.

\subsection{Statistical Analysis}

The relative mRNA expression levels and FPKM values are expressed as mean \pm standard error (SE). The one-way ANOVA with Tukey's post hoc test was used to evaluate the significant differences between 20 vs. 30 ppt and 30 vs. 40 ppt groups. The significance level was set at $\alpha=0.05$. The Statistical Package for the Social Sciences (SPSS) 16.0 (SPSS, Chicago, IL, USA) was used for all statistical analyses.

\section{Results}

\subsection{Illumina Sequencing}

The gill transcriptome can provide a valuable RNA resource for future analysis of greater amberjack adaptability to salinity and artificial culture. The HiSeq X Ten platform was used for RNA sequencing of gill samples at 20, 30, and 40 ppt. A total of 94.79, 93.66, and 78.83 million clean reads were obtained at 20 (G20), 30 (G30), and 40 ppt (G40), respectively, after quality control. The Q30 values and GC content of the clean reads were more than $95 \%$ and $49 \%$, respectively. The high-quality reads were used for further analysis. The reads' Q20 and Q30 values, GC content, and transcript numbers for each cDNA library are shown in Table 1. 
Table 1. Summary statistics of greater amberjack gill transcriptome sequencing data.

\begin{tabular}{cccccc}
\hline Samples & $\begin{array}{c}\text { Clean } \\
\text { Reads }\end{array}$ & $\begin{array}{c}\text { Clean } \\
\text { Bases }\end{array}$ & $\begin{array}{c}\text { GC Contents } \\
\mathbf{( \% )}\end{array}$ & $\begin{array}{c}\text { Clean Reads } \\
\text { Q20 (\%) }\end{array}$ & $\begin{array}{c}\text { Clean Reads } \\
\text { Q30 (\%) }\end{array}$ \\
\hline G20-1 & $33,618,558$ & $10,069,190,306$ & 49.64 & 98.66 & 95.70 \\
G20-2 & $30,542,362$ & $9,149,565,768$ & 49.59 & 98.63 & 95.63 \\
G20-3 & $30,626,059$ & $9,174,115,482$ & 49.82 & 98.59 & 95.51 \\
G30-1 & $29,118,900$ & $8,723,118,946$ & 49.98 & 98.65 & 95.68 \\
G30-2 & $30,326,490$ & $9,084,622,756$ & 50.10 & 98.64 & 95.62 \\
G30-3 & $34,209,823$ & $10,247,870,004$ & 49.86 & 98.61 & 95.59 \\
G40-1 & $26,628,061$ & $7,974,715,550$ & 50.08 & 98.49 & 95.35 \\
G40-2 & $29,931,391$ & $8,964,260,212$ & 49.86 & 98.63 & 95.72 \\
G40-3 & $22,273,974$ & $6,672,988,308$ & 49.68 & 98.60 & 95.63 \\
\hline
\end{tabular}

a 1, 2, and 3: three independent biological replicates; ${ }^{\mathrm{b}}$ Q20: the percentage of bases with a Phred value $>20$ ${ }^{c} \mathrm{Q} 30$ : the percentage of bases with a Phred value $>30$.

\subsection{Annotation and Functional Analysis of the Gill Transcriptome}

In total, 23,972 genes were annotated. A total of 23,950 (99.91\%); 22,838 (95.27\%); $21,503(89.70 \%) ; 16,505$ (68.85\%); 15,991 (66.71\%); 14,525 (60.59\%); 14,970 (62.45\%); and 7382 $(30.79 \%)$ were annotated in the NR, eggNOG, Pfam, Swiss-Prot, KOG, GO, KEGG, and COG databases, respectively (Table 2). The annotated genes provided the basis for further analysis of the specific molecular processes in greater amberjack.

Table 2. Greater amberjack gill transcriptome annotation statistics.

\begin{tabular}{ccc}
\hline Category & Number & Percentage (\%) \\
\hline Total number of annotated genes & 23,972 & \\
Gene matches against GO & 14,525 & 60.59 \\
Gene matches against KEGG & 14,970 & 62.45 \\
Gene matches against KOG & 15,991 & 66.71 \\
Gene matches against Swiss-Prot & 16,505 & 68.85 \\
Gene matches against NR & 23,950 & 99.91 \\
Gene matches against Pfam & 21,503 & 89.70 \\
Gene matches against COG & 7382 & 30.79 \\
Gene matches against eggNOG & 22,838 & 95.27 \\
\hline
\end{tabular}

GO: gene ontology; KEGG: Kyoto Encyclopedia of Genes and Genomes; KOG: Eukaryotic orthologous group; NR: non-redundant; Pfam: Pfam protein families database; COG: clusters of orthologous groups; eggNOG: evolutionary genealogy of genes: non-supervised orthologous groups.

The best BLAST results of reads were enriched for closely related fish species, including Seriola lalandi $(6.24 \%)$, Lates calcarifer $(2.09 \%)$, Larimichthys crocea $(1.49 \%)$, Stegastes partitus $(0.63 \%)$, Oreochromis niloticus (0.55\%), and other species (4.98\%) (Figure 1$)$.

\subsection{Identification and Analysis of Differentially Expressed Genes (DEGs)}

A total of 417 (205 up-regulated and 212 down-regulated) and 18 (nine up-regulated and nine down-regulated) DEGs were identified in the G30 vs. G20 and G30 vs. G40 groups, respectively, using DESeq2 software, FDR-adjusted $p$-value $<0.05$ and I $\log 2$ (fold change) $I \geq 1$ (Figure 2). Heat maps of the clustered DEGs under hypo- and hyper-salinity stresses are shown in Figure 3. The top 20 DEGs in the G30 vs. G20 group and the top 18 DEGs in the G30 vs. G40 group are shown in Table 3. 


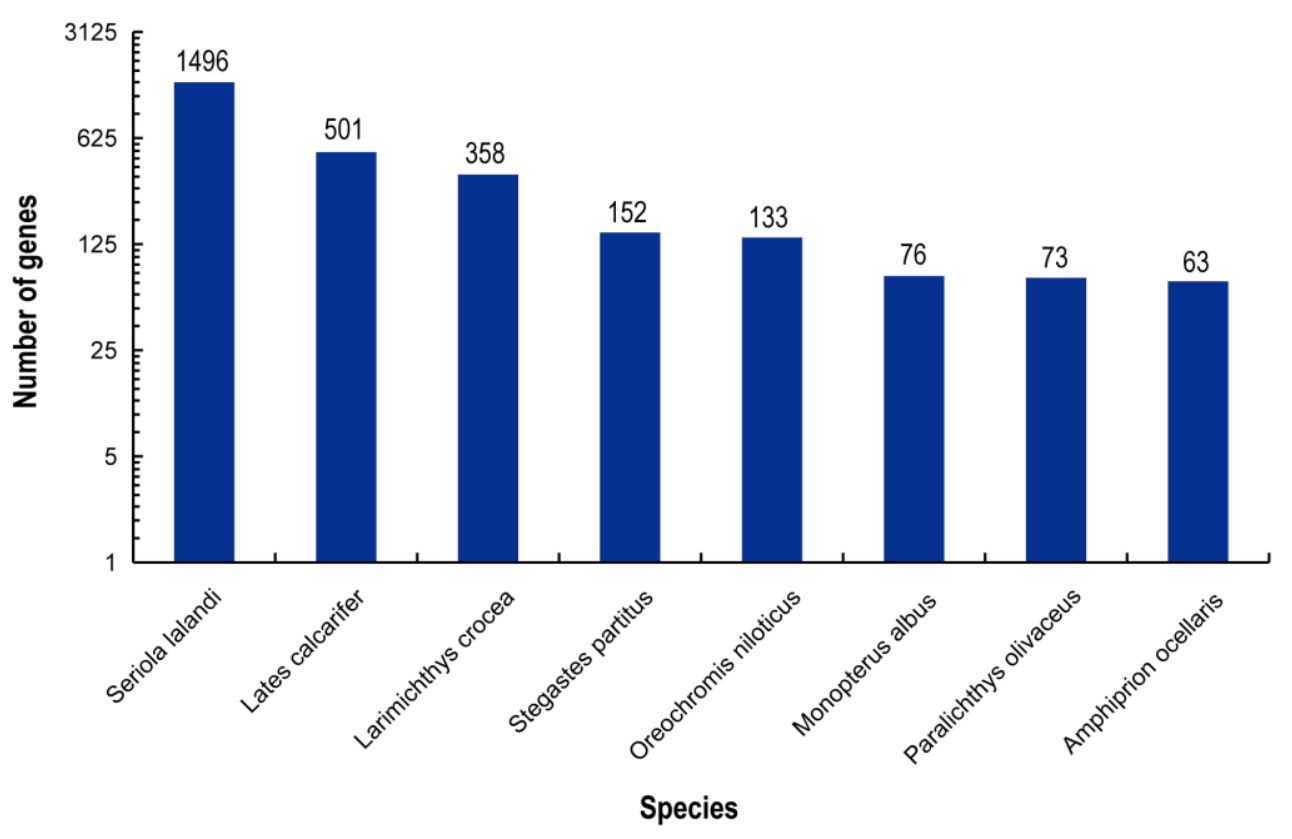

Figure 1. Species distribution in the Nr database. Vertical axis: the number of annotated sequences matching each species. Horizontal axis: the distribution of top species that match the annotated sequences.

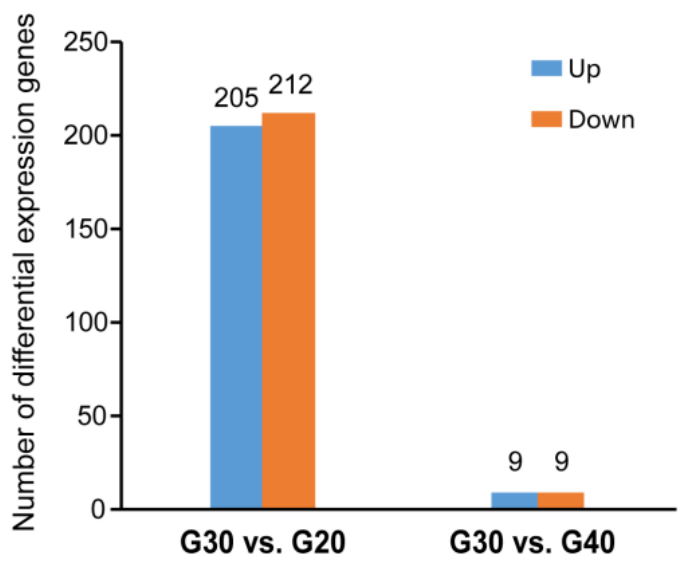

(a)

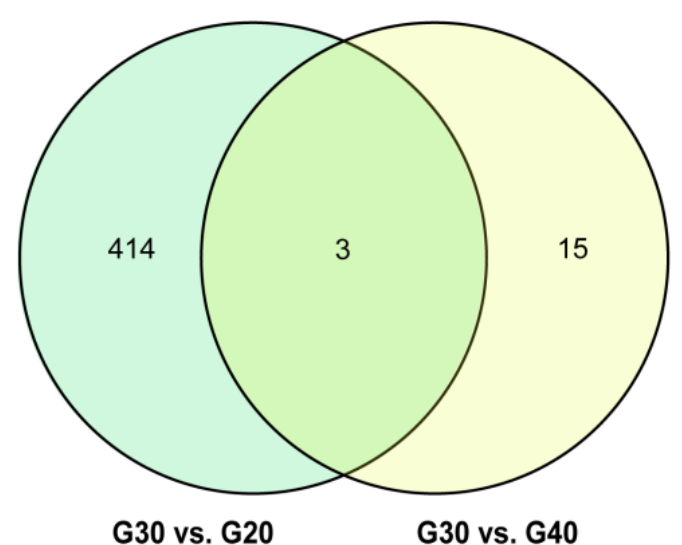

(b)

Figure 2. (a) The differentially expressed genes (DEGs) in the G30 vs. G20 group and the G30 vs. G40 group. The horizontal axis represents the G30 vs. G20 group and the G30 vs. G40 group, and the vertical axis indicates the gene numbers. The blue and orange colors represent the upand down-regulated DEGs, respectively. (b) Number of DEGs and Venn diagram of the overlap of the groups. 

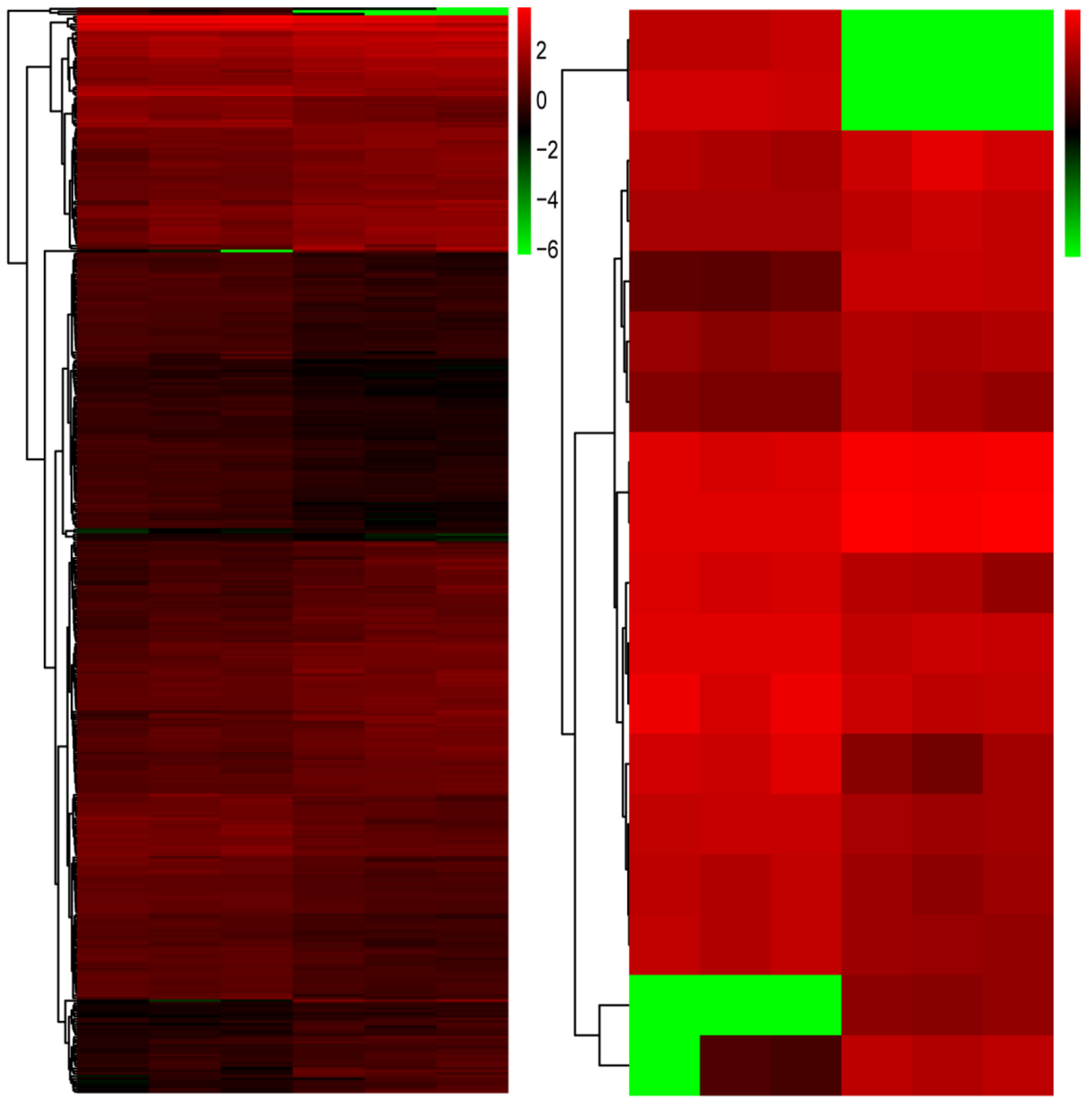

$\begin{array}{llllll}9 & 0 & 0 & 0 & 0 & 0 \\ \omega & \omega & \omega & N & N & 0 \\ 0 & 0 & 0 & 0 & 0 & 0 \\ 1 & 1 & 1 & 1 & 1 & 1 \\ 1 & N & \omega & 1 & N & \omega\end{array}$

(a)

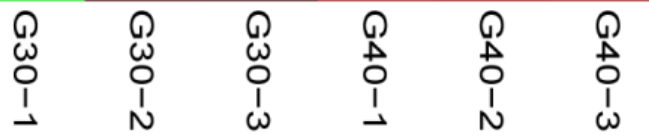

(b)

Figure 3. Expression heatmap of the DEGs in G30 vs. G20 group (a) and G30 vs. G40 group (b). Green and red squares indicate down- and up-regulation, respectively. The brighter colors indicate the significant fold changes. 
Table 3. Top 20 DEGs in G30 vs. G20 group and top 18 DEGs in G30 vs. G40 group.

\begin{tabular}{|c|c|c|}
\hline Gene Names & $\log 2 \mathrm{FC}$ & Description \\
\hline \multicolumn{3}{|l|}{ G30 vs. G20 } \\
\hline Seriola_dumerili_newGene_5930 & 2.80986 & protein NLRC3-like \\
\hline Seriola_dumerili_newGene_10944 & 2.51744 & unnamed protein product \\
\hline LOC111226299 & 2.19450 & C-type lectin domain family 4 member F-like \\
\hline LOC111229131 & 2.14477 & growth/differentiation factor 8-like \\
\hline frmd3 & 2.09078 & FERM domain-containing protein 3 \\
\hline LOC111231723 & 1.99161 & uncharacterized protein LOC111231723 \\
\hline lyve1 & 1.97051 & $\begin{array}{c}\text { lymphatic vessel endothelial hyaluronic acid } \\
\text { receptor } 1\end{array}$ \\
\hline LOC111239963 & 1.92871 & solute carrier family 12 member 3-like \\
\hline slc5a6a & 1.81352 & solute carrier family 5 member $6 a$ \\
\hline Seriola_dumerili_newGene_13911 & 1.75102 & macrophage mannose receptor 1-like \\
\hline LOC111240141 & -3.71184 & E3 ubiquitin-protein ligase TRIM21-like \\
\hline Seriola_dumerili_newGene_14148 & -3.58766 & pol-like protein \\
\hline LOC111223147 & -2.40705 & uncharacterized protein LOC111223147 \\
\hline satb1a & -2.38908 & SATB homeobox 1a \\
\hline ribc2 & -2.22092 & RIB43A domain with coiled-coils 2 \\
\hline$w n t 7 b b$ & -2.09191 & $\begin{array}{l}\text { wingless-type MMTV integration site family, } \\
\text { member 7Bb }\end{array}$ \\
\hline LOC111228626 & -2.01800 & interferon-induced protein 44 -like \\
\hline $\operatorname{trabd} 2 a$ & -1.94610 & TraB domain containing $2 \mathrm{~A}$ \\
\hline Seriola_dumerili_newGene_12544 & -1.85641 & Retrotransposable element Tf 2 protein type 1 \\
\hline LOC111220383 & -1.70808 & gastrula zinc finger protein XICGF57.1-like \\
\hline \multicolumn{3}{|l|}{ G30 vs. G40 } \\
\hline Seriola_dumerili_newGene_10944 & 2.67769 & unnamed protein product \\
\hline LOC111231293 & 1.50771 & C-X-C motif chemokine 10-like \\
\hline LOC111219635 & 1.47708 & intraflagellar transport protein 140 homolog \\
\hline $\operatorname{slc} 4 a 4 a$ & 1.24110 & solute carrier family 4 member $4 \mathrm{a}$ \\
\hline$c f t r$ & 1.23478 & $\begin{array}{l}\text { cystic fibrosis transmembrane conductance } \\
\text { regulator }\end{array}$ \\
\hline camkla & 1.14853 & $\begin{array}{l}\text { calcium/calmodulin-dependent protein } \\
\text { kinase type 1-like }\end{array}$ \\
\hline LOC111224523 & 1.01042 & kinesin-like protein KIF21A \\
\hline $\operatorname{map} 7 d 2 b$ & 1.00381 & MAP7 domain containing $2 \mathrm{~b}$ \\
\hline LOC111235326 & -3.05319 & pleckstrin-like \\
\hline LOC111220915 & -2.00153 & ladderlectin-like \\
\hline LOC111235291 & -1.29715 & indoleamine 2,3-dioxygenase 2-like \\
\hline LOC111240189 & -1.15190 & GTPase IMAP family member 7-like \\
\hline sqle & -1.12522 & squalene monooxygenase \\
\hline LOC111228808 & -1.08252 & $\mathrm{C}-\mathrm{X}-\mathrm{C}$ chemokine receptor type 4 -like \\
\hline Seriola_dumerili_newGene_4780 & -1.03479 & $\begin{array}{l}\text { nuclear receptor subfamily } 1 \text { group D } \\
\text { member 1-like }\end{array}$ \\
\hline$n r 1 d 1$ & -1.03175 & $\begin{array}{l}\text { nuclear receptor subfamily } 1 \text {, group } \mathrm{d}, \\
\text { member } 1\end{array}$ \\
\hline LOC111236503 & -1.01894 & granzyme A-like \\
\hline
\end{tabular}

\subsection{DEG Annotation and Pathway Analysis}

Some enriched KEGG pathways related to Seriola dumerili metabolism and molecular signaling pathway were identified, including steroid biosynthesis, cytokine-cytokine receptor interaction, porphyrin and chlorophyll metabolism, cytosolic DNA-sensing pathway, the intestinal immune network for IgA production, and tryptophan metabolism (Figures 4 and 5). The top 10 enriched KEGG pathways of the DEGs under hypo- and hyper-salinity stresses are shown in Table 4. 


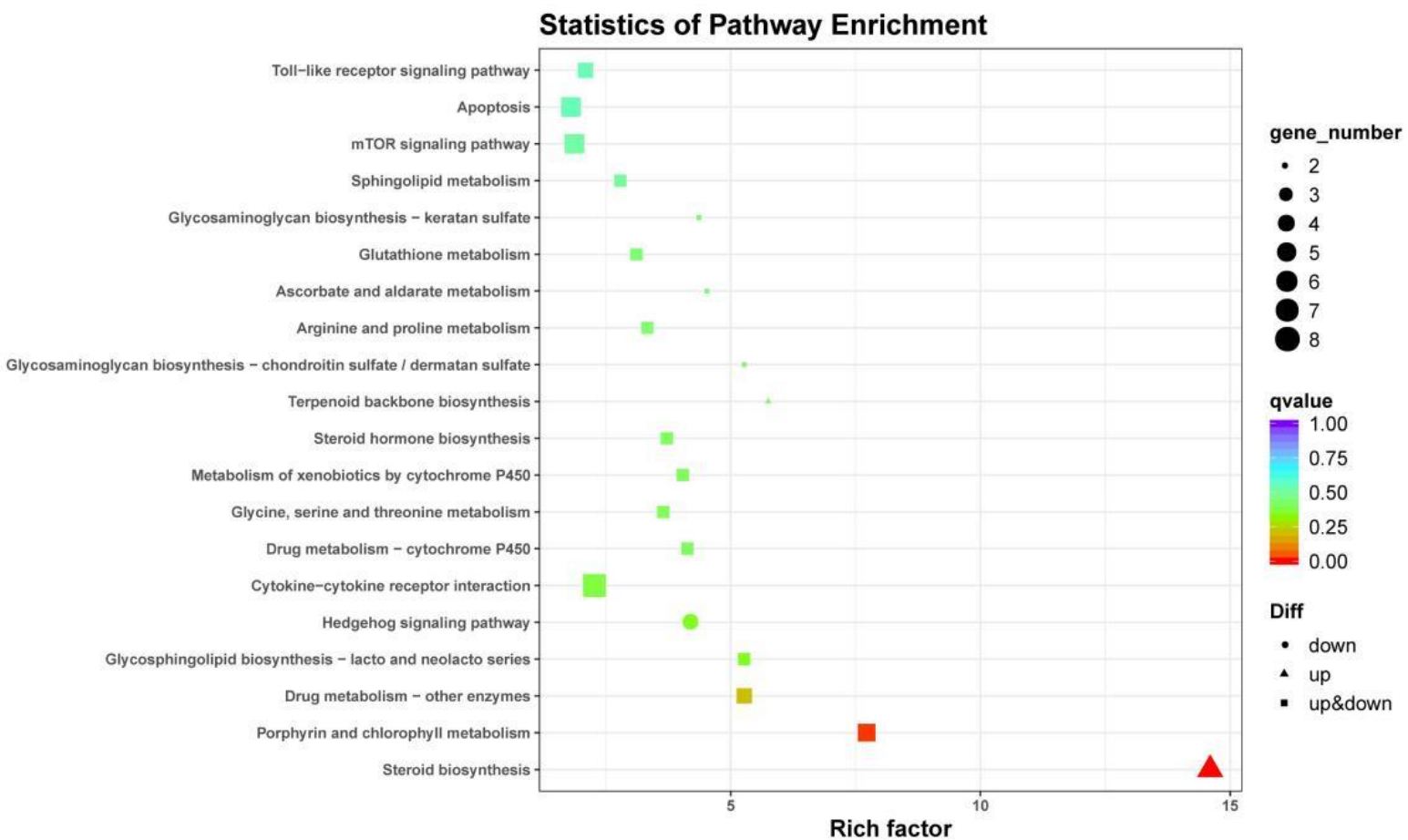

Figure 4. KEGG pathway enrichment analyses of DEGs in the G30 vs. G20 group. The size of each pathway represents the number of enriched targeted genes.

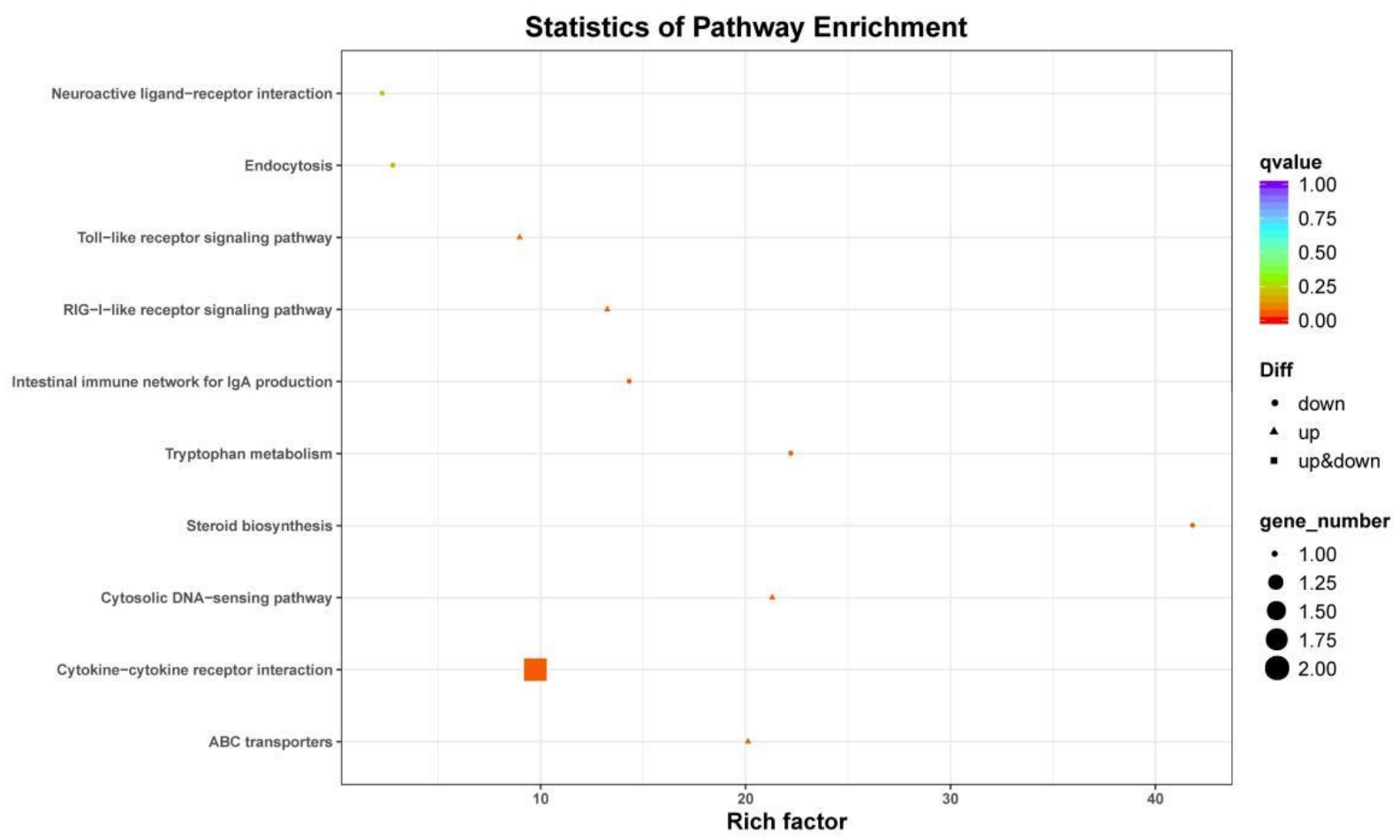

Figure 5. KEGG pathway enrichment analyses of DEGs in the G30 vs. G40 group. The size of each pathway represents the number of enriched targeted genes. 
Table 4. Top 10 KEGG pathways of DEGs in G30 vs. G20 and G30 vs. G40 groups.

\begin{tabular}{|c|c|c|}
\hline Pathway ID & Pathway Term & Gene Name \\
\hline \multicolumn{3}{|l|}{ G30 vs. G20 } \\
\hline ko04060 & $\begin{array}{c}\text { Cytokine-cytokine receptor } \\
\text { interaction }\end{array}$ & $\begin{array}{c}\text { LOC111221262, LOC111222833, LOC111224301, } \\
\text { LOC111225535, LOC111230808, LOC111231248, edar, } \\
\text { tnfsf12 }\end{array}$ \\
\hline ko04210 & Apoptosis & $\begin{array}{c}\text { LOC111218420, LOC111225343, LOC111228846, } \\
\text { LOC111230905, bcl2l11, pik3cb }\end{array}$ \\
\hline ko00100 & Steroid biosynthesis & LOC111222971,ebp, lss, msmo1, nsdhl, sqle \\
\hline ko04150 & mTOR signaling pathway & $\begin{array}{l}\text { LOC111220460, LOC111228846, LOC111229726, } \\
\text { LOC111238290, pik3cb, wnt4 }\end{array}$ \\
\hline ko00860 & $\begin{array}{l}\text { Porphyrin and chlorophyll } \\
\text { metabolism }\end{array}$ & $\begin{array}{c}\text { newGene_6606, LOC111217420, LOC111219041, } \\
\text { LOC111226879, LOC111237667 }\end{array}$ \\
\hline ko04020 & Calcium signaling pathway & newGene_6757, LOC111224354, LOC111230822, nos1, ptafr \\
\hline ko04510 & Focal adhesion & LOC111228846, LOC111231768, itga9, pak5, pik3cb \\
\hline ko04340 & Hedgehog signaling pathway & LOC111228096, evc, hhip, ptch1 \\
\hline ko00240 & Pyrimidine metabolism & LOC111217958, LOC111221687, cda, cmpk2 \\
\hline ko04060 & $\begin{array}{c}\text { Cytokine-cytokine receptor } \\
\text { interaction }\end{array}$ & $\begin{array}{c}\text { LOC111221262, LOC111222833, LOC111224301, } \\
\text { LOC111225535, LOC111230808, LOC111231248, edar, } \\
\text { tnfsf12 }\end{array}$ \\
\hline \multicolumn{3}{|l|}{ G30 vs. G40 } \\
\hline ko00380 & Tryptophan metabolism & LOC111235291 \\
\hline ko04144 & Endocytosis & LOC111228808 \\
\hline ko02010 & $\mathrm{ABC}$ transporters & $c f t r$ \\
\hline ko04060 & $\begin{array}{c}\text { Cytokine-cytokine receptor } \\
\text { interaction }\end{array}$ & LOC111228808, LOC111231293 \\
\hline ko04623 & $\begin{array}{l}\text { Cytosolic DNA-sensing } \\
\text { pathway }\end{array}$ & LOC111231293 \\
\hline ko04672 & $\begin{array}{l}\text { Intestinal immune network for } \\
\text { IgA production }\end{array}$ & LOC111228808 \\
\hline ko00100 & Steroid biosynthesis & sqle \\
\hline ko04620 & $\begin{array}{l}\text { Toll-like receptor signaling } \\
\text { pathway }\end{array}$ & LOC111231293 \\
\hline ko04622 & $\begin{array}{l}\text { RIG-I-like receptor signaling } \\
\text { pathway }\end{array}$ & LOC111231293 \\
\hline
\end{tabular}

\subsection{Validation of RNA Sequencing Data by QPCR}

Considering the top 20 most important salinity stress responses of DEGs identified in the transcriptomic analysis, which had been reported in the previous studies, nine genes were selected for RNA sequencing data validation using qPCR (Figure 6). The mRNA expression of $e b p, m s m o 1, n s d h l$, sqle, lss, and ogdh was significantly increased in the G20 group, while that of $e b p, m s m o 1$, and sqle was significantly decreased, compared with the G30 group. However, the mRNA expression of $n s d h l$, lss, and ogdh showed no difference between the G40 and G30 groups. The results were consistent with the RNA sequencing analysis results conducted using qPCR. Moreover, the mRNA expression of edar, wnt4, slc25a48 were decreased in the G20 group. However, the mRNA expression of edar and slc25a48 showed no difference between the G40 and G30 groups. Interestingly, the expression of these genes showed no differences at 15 days (Figure S1). 


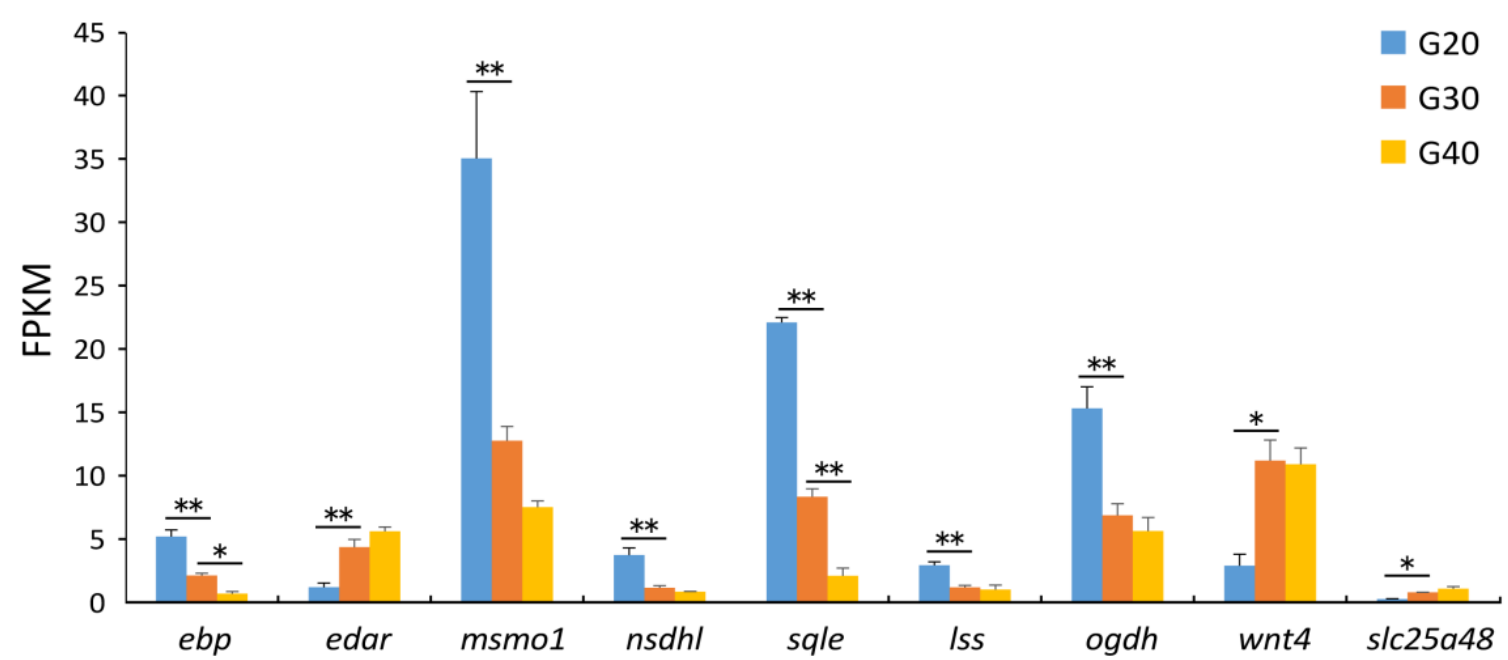

(a)

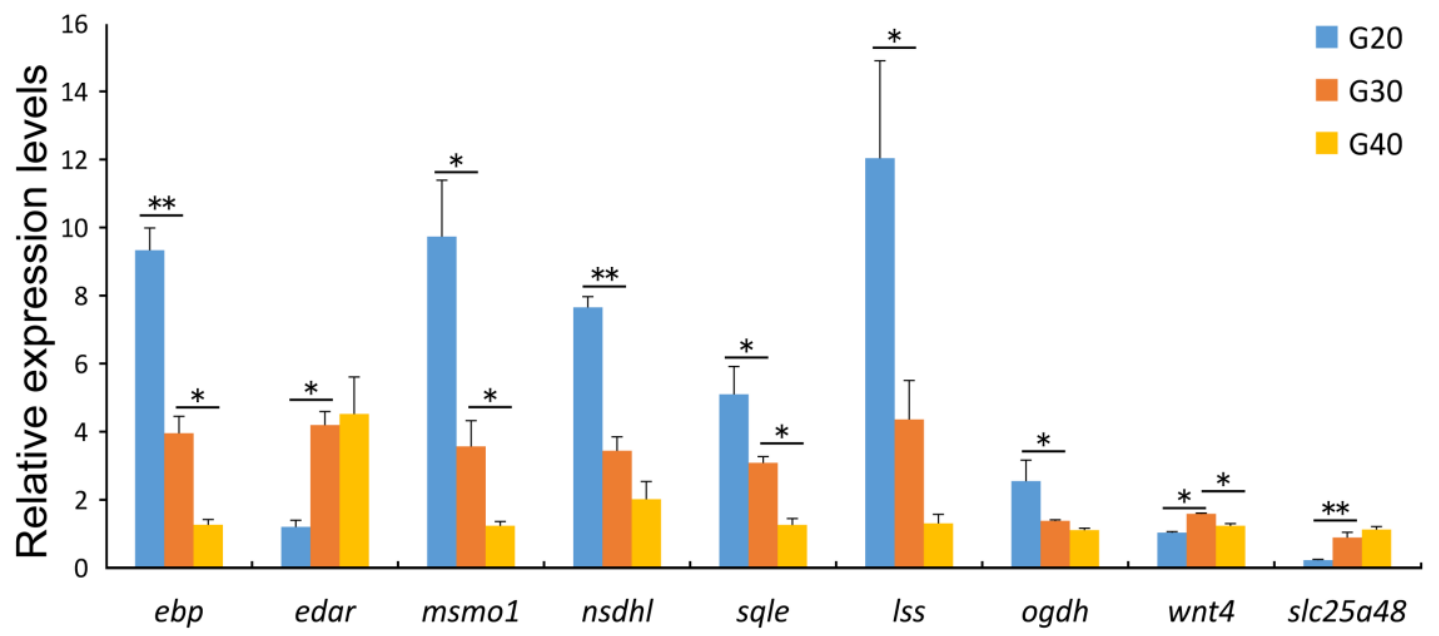

(b)

Figure 6. Expression of the nine validated genes in the G20, G30, and G40 group at 30 days. (a) The FPKM value detected by RNA sequencing. (b) The relative expression values measured using qPCR. The relative expression level of mRNA transcripts was detected using qPCR via the $2^{-\Delta \Delta C t}$ method. Data are expressed as means $\pm \mathrm{SE}(n=3)$. The asterisks ${ }^{*}$ and ${ }^{* *}$ indicate statistical differences at $p<0.05$ and $p<0.01$, respectively, as determined by one-way ANOVA with Tukey's post hoc test. $\beta$-actin was used as the reference gene.

\section{Discussion}

\subsection{Transcriptomic Analysis of Differentially Expressed Genes}

Salinity alterations can lead to various physiological reactions to maintain homeostasis, including osmotic regulation, ion transports, and respiratory metabolism [55]. For instance, low (12 ppt) and high salinity water (32 ppt) can significantly induce some specific pathways in gills of silvery pomfret (Pampus argenteus), including calcium transport, neuroactive ligand-receptor interaction, NOD-like receptor signaling, Toll-like receptor signaling, and cytokine-cytokine receptor interaction pathway, indicating that salinity stress affects the immune system and osmotic pressure-regulated pathways [30]. Moreover, low salinity stress (6 ppt) affects ion transport, immune response, energy metabolism, and protein synthesis in marbled flounder (Pseudopleuronectes yokohamae) [9]. A total of 417 DEGs (205 up-regulated and 212 down-regulated) in the 30 ppt vs. 20 ppt group and 18 DEGs (nine up-regulated and nine down-regulated) in the 30 ppt vs. 40 ppt group were identified. 
KEGG analysis showed that the DEGs were mainly enriched in the cytokine-cytokine receptor interaction, apoptosis, steroid biosynthesis, and mTOR signaling pathways, similar to cobia (Rachycentron canadum) [31]. As discussed below, the DEGs were involved in several potential complex molecular biological processes in the gill.

\subsection{DEGs Involved in Steroid Biosynthesis and Lipid Metabolism}

Steroid hormones, such as epinephrine and cortisol, can influence the metabolic capacity of the gill [56]. Epinephrine induces glycogenolysis after exposure to stress, thus increasing the plasma glucose level, which provides energy for the target tissue, including gill, to transfer ions like $\mathrm{Na}^{+}$[57]. In addition, cortisol can stimulate active $\mathrm{Ca}^{2+}$ uptake under asymmetrical conditions, thus regulating the tight junction morphology between pavement cells of euryhaline fish $[56,58]$. Herein, KEGG pathway analysis showed that some DEGs (ebp, lss, sqle, nsdhl, msmo1, sc5d, dhcr7, and dhcr24) were involved in the steroid biosynthesis pathways under the long-term hyper-salinity (40 ppt) and hypo-salinity (20 ppt) stresses. Moreover, salinity stress (from 20 to $40 \mathrm{ppt}$ ) decreased the mRNA expression levels of sqle, $m s m o 1$, and $e b p$. Ebp (Emopamil binding protein), also known as EBP cholestenol delta-isomerase, is essential in the sterol biosynthesis pathway [59]. Sterols are essential cell membrane components and transporters in many biofilms [60]. SQLE (squalene epoxidase) is rate limiting and the first oxygenation enzyme in cholesterol synthesis [61]. Lanosterol, especially cholesterol, is the upstream precursor of sterol biosynthesis in fungal steroids and animals [62]. Herein, hypo-salinity up-regulated sqle, ebp, and lss in the gills, indicating the stimulation of cholesterol synthesis in the gills. Studies have shown that $l s s$ and dhcr 24 are up-regulated in $O$. niloticus and Rachycentron canadum under hypo-salinity [31,63], consistent with this study.

Msmo1 is a key cholesterol biosynthetic enzyme. Nsdhl regulates adipogenesis via a synergized expression pattern with Msmo1 [64-67]. Herein, hypo-salinity up-regulated both $n s d h l$ and $m s m o 1$, indicating that hypo-salinity can affect adipogenesis in greater

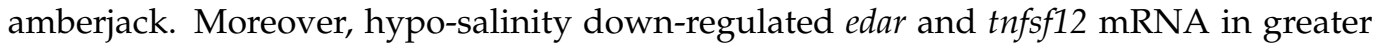
amberjack. Studies have shown that EDAr (ectodysplasin A receptor), belonging to the tumor necrosis factor receptor (TNFr) superfamily, can regulate cell activities, such as differentiation, proliferation, maturation, and lipid metabolism, by binding to the ectodysplasin A1 (EDA1) [68-71]. A previous study showed that $t n f s f 12$ (TNF superfamily member 12) can inhibit lipid deposition in a dose-dependent manner without any cytotoxic effects. However, an agonistic antibody of the $t n f s f 12$ receptor can alleviate the repression [72]. Herein, hypo-salinity decreased the mRNA expression of $\operatorname{tnfsf12}$ in gill, indicating that lipid deposition is essential under low salinity stress. Previous reports have suggested that lipids are the energy source for euryhaline fish under osmotic stress $[49,73]$. Therefore, more lipids may be produced in greater amberjack under salinity changes by regulating the steroid biosynthesis related to lipid metabolism, adipogenesis, and lipid deposition, as revealed in other fish species [18]. The Ogdh enzyme is a key entry point for carbon into the Krebs cycle. Moreover, it affects all redox signals in mitochondria and cells [74,75]. Herein, hypo-salinity significantly increased the mRNA expression of $o g d h \mathrm{mR}$, implying that adequate energy is needed in gills under salinity changes.

\subsection{DEGs Involved in Ion Transport}

Solute transport protein (solute carrier SLC) is the largest class of intracellular transport proteins, with over 300 members, mostly located in cell membranes. They mainly facilitate the transport of various substrates, including amino acids, nucleotides, glucose, and inorganic ions, across biological membranes [39]. Some of these proteins (slc5a6a, slc $4 a 1 a, \operatorname{slc} 4 a 4 a$ ) had different expression patterns between the hypo-salinity and control groups. The SLC4 gene family mediates $\mathrm{HCO}^{-}$extrusion and $\mathrm{Cl}^{-}$uptake across cellular plasma membranes, thus regulating the cell volume and intracellular $\mathrm{pH}$ and stabilizing resting membrane potential through the regulation of cytoplasmic $\mathrm{Cl}^{-}$[76]. Moreover, slc4ala and slc4a1b are positively correlated with NKA $\left(\mathrm{Na}^{+} / \mathrm{K}^{+}\right.$-ATPase) [77]. Herein, 
slc4a1a was down-regulated in the hypo-salinity group, while it was up-regulated in the hyper-salinity group, indicating the ion exchange in the gills.

Cystic fibrosis transmembrane conductance regulator (CFTR), an $A B C$ transporter, acts as a channel across the cell membrane for transporting $\mathrm{Cl}^{-}$into and out of cells. Hypersalinity increases $c f t r$ expression in striped bass (Morone saxatilis) [78]. Moreover, $c f t r$ mRNA levels are significantly increased in gills of killifish (Fundulus heteroclitus) and Atlantic salmon (Salmo salar) under seawater conditions $[79,80]$. Similarly, this study showed that cftr was up-regulated in the hyper-salinity group, indicating the $\mathrm{Cl}^{-}$transport changes.

Aquaporins (AQPs) are a family of integral membrane proteins that facilitate water transport across biological membranes along an osmotic gradient [81]. Thirteen AQP isoforms (AQP0-AQP12) have been identified in humans and rodents [40]. However, AQP4 has the most potential for high water permeability [82]. Herein, the expression of aqp4 was significantly decreased in the hypo-salinity group compared with the control group, indicating the possible water permeability changes.

\subsection{DEGs Involved in Immune Response}

Previous studies have shown that the changes in fish immune status depend on the intensity and duration of the environmental stresses [83]. Herein, several DEGs (wnt4, slc $25 a 48$, slc $6 a 8$, tlr 5 , etc.) related to immune responses were found in the gill transcriptome of greater amberjack. Studies have reported that wht genes enhance defense against pathogenic virus infection in the innate immune of Litopenaeus vannamei [84]. Moreover, Wnt4 protein can stimulate white blood cells and thymopoiesis in mice [85]. Herein, wnt4 was significantly down-regulated in the hypo-salinity group, indicating that low salinity can affect the immune system of the greater amberjack.

Toll-like receptors (TLRs) are key pathogen pattern recognition receptors that control the host immune responses against pathogens by recognizing molecular patterns specific to microorganisms [86]. Previous studies have reported that $t l r 5$ plays a crucial role in the immune responses of turbot (Scophthalmus maximus L.) to the infections of various pathogens [87]. For instance, TLR5 stimulates the expression of proinflammatory, antibacterial, and stress-related genes by binding to bacterial flagellin, thus enhancing host defense against bacterial pathogens [88]. Moreover, flagellin increases Tlr5 activity and the release of its downstream factor, IL-8 in mice [88,89]. Herein, the expression level of tlr5 was decreased in the hypo-salinity group, indicating that low salinity inhibits tlr 5 activity on key adaptive functions, thus lowering efficient immune responses.

\section{Conclusions}

This work used transcriptome analysis to investigate the molecular changes in gills of greater amberjack (Seriola dumerili) under three different salinity concentrations $(20,30$, and $40 \mathrm{ppt})$. The results provided large transcriptome data, abundant DEGs, and signaling pathways related to salinity adaptation. The signaling pathways analysis indicated that a complex molecular regulatory network is involved in metabolism, including steroid synthesis, lipid metabolism, tryptophan metabolism, ion transporters, and immune response for adaptation to salinity stress. Therefore, this study can provide insights into the molecular mechanisms of greater amberjack adaptation to salinity.

Supplementary Materials: The following are available online at https: / / www.mdpi.com/article/ 10.3390/ani12030327/s1, Figure S1: Relative expression levels of different genes in RT-PCR (samples taken on the 15th day); Table S1: Primer sequences used in this study.

Author Contributions: Conceptualization, Y.P., H.S., Y.H. and G.L.; methodology, Y.P., H.S. and Y.L.; formal analysis, Y.P., H.S. and Y.H.; investigation: Y.P., H.S., Y.L., Y.H., R.Z., D.J. and M.J.; writingoriginal draft preparation, Y.P. and H.S.; writing—review and editing, Y.P., H.S. and G.L.; supervision, C.Z. and G.L. All authors have read and agreed to the published version of the manuscript. 
Funding: This research was financed by the Fund of Southern Marine Science and Engineering Guangdong Laboratory (Zhanjiang) (ZJW-2019-06), Key Project of “Blue Granary Science and Technology Innovation" of the Ministry of Science and Technology (2018YFD0901203).

Institutional Review Board Statement: The study was conducted according to the guidelines of the Decla-ration of Helsinki, and approved by the Institutional Animal Care and Use Committee (IACUC), Fisheries College, Guangdong Ocean University (Approval No.: GDOU-IACUC-2021A1220, 20 December 2021)

\section{Informed Consent Statement: Not applicable.}

Data Availability Statement: The raw data of Illumina transcriptome have been submitted in the SRA under accession number PRJNA783747 (SRR17041711-SRR17041719).

Conflicts of Interest: The authors declare no conflict of interest.

\section{References}

1. Holmer, M. Environmental issues of fish farming in offshore waters: Perspectives, concerns and research needs. Aquac. Environ. Interact. 2010, 1, 57-70. [CrossRef]

2. Seth, H.; Axelsson, M. Sympathetic, parasympathetic and enteric regulation of the gastrointestinal vasculature in rainbow trout (Oncorhynchus mykiss) under normal and postprandial conditions. J. Exp. Biol. 2010, 213, 3118-3126. [CrossRef] [PubMed]

3. Perry, S.F.; Capaldo, A. The autonomic nervous system and chromaffin tissue: Neuroendocrine regulation of catecholamine secretion in non-mammalian vertebrates. Auton. Neurosci. 2011, 165, 54-66. [CrossRef] [PubMed]

4. Jeffrey, J.D.; Esbaugh, A.J.; Vijayan, M.M.; Gilmour, K.M. Modulation of hypothalamic-pituitary-interrenal axis function by social status in rainbow trout. Gen. Comp. Endocrinol. 2012, 176, 201-210. [CrossRef] [PubMed]

5. Schulte, P.M. What is environmental stress? Insights from fish living in a variable environment. J. Exp. Biol. 2014, 217, 23-34. [CrossRef] [PubMed]

6. Kammerer, B.D.; Sardella, B.A.; Kultz, D. Salinity stress results in rapid cell cycle changes of tilapia (Oreochromis mossambicus) gill epithelial cells. J. Exp. Zool. Part A Ecol. Genet. Physiol. 2009, 311, 80-90. [CrossRef]

7. Wen, X.; Chu, P.; Xu, J.; Wei, X.; Fu, D.; Wang, T.; Yin, S. Combined effects of low temperature and salinity on the immune response, antioxidant capacity and lipid metabolism in the pufferfish (Takifugu fasciatus). Aquaculture 2021, 531, 735886. [CrossRef]

8. Guo, T.; Yang, Y.; Meng, F.; Wang, S.; Xia, S.; Qian, Y.; Li, M.; Wang, R. Effects of low salinity on gill and liver glycogen metabolism of great blue-spotted mudskippers (Boleophthalmus pectinirostris). Comp. Biochem. Physiol. Part C 2020, 230, 108709. [CrossRef] [PubMed]

9. Cui, Q.; Qiu, L.; Yang, X.; Shang, S.; Yang, B.; Chen, M.; Liu, X.; Chen, B.; Fu, X.; Wang, W.; et al. Transcriptome profiling of the low-salinity stress responses in the gills of the juvenile Pseudopleuronectes yokohamae. Comp. Biochem. Physiol. Part D 2019, 32, 100612. [CrossRef]

10. Xu, Z.; Gan, L.; Li, T.; Xu, C.; Chen, K.; Wang, X.; Qin, J.G.; Chen, L.; Li, E. Transcriptome profiling and molecular pathway analysis of genes in association with salinity adaptation in nile tilapia Oreochromis niloticus. PLoS ONE 2015, 10, e0136506. [CrossRef]

11. Zhou, Z.; Hu, F.; Li, W.; Yang, X.; Hallerman, E.; Huang, Z. Effects of salinity on growth, hematological parameters, gill microstructure and transcriptome of fat greenling Hexagrammos otakii. Aquaculture 2021, 531, 735945. [CrossRef]

12. Xiong, Y.; Dong, S.; Huang, M.; Li, Y.; Wang, X.; Wang, F.; Ma, S.; Zhou, Y. Growth, osmoregulatory response, adenine nucleotide contents, and liver transcriptome analysis of steelhead trout (Oncorhynchus mykiss) under different salinity acclimation methods. Aquaculture 2020, 520, 734937. [CrossRef]

13. Handayani, K.S.; Soegianto, A.; Chang, C.-F. Effect of salinity on osmoregulation and histopathology in gills of tilapia (Oreochromis niloticus). Asian J. Water Environ. Pollut. 2020, 17, 7-11. [CrossRef]

14. Lin, Y.T.; Hu, Y.C.; Wang, Y.C.; Hsiao, M.Y.; Lorin-Nebel, C.; Lee, T.H. Differential expression of two ATPases revealed by lipid raft isolation from gills of euryhaline teleosts with different salinity preferences. Comp. Biochem. Physiol. Part B 2021, $253,110562$. [CrossRef] [PubMed]

15. Mohamed, N.A.; Saad, M.F.; Shukry, M.; El-Keredy, A.M.S.; Nasif, O.; Van Doan, H.; Dawood, M.A.O. Physiological and ion changes of Nile tilapia (Oreochromis niloticus) under the effect of salinity stress. Aquac. Rep. 2021, 19, 100567. [CrossRef]

16. Fiol, D.F.; Chan, S.Y.; Kultz, D. Identification and pathway analysis of immediate hyperosmotic stress responsive molecular mechanisms in tilapia (Oreochromis mossambicus) gill. Comp. Biochem. Physiol. Part D 2006, 1, 344-356. [CrossRef]

17. Gjessing, M.C.; Krasnov, A.; Timmerhaus, G.; Brun, S.; Afanasyev, S.; Dale, O.B.; Dahle, M.K. The Atlantic salmon gill transcriptome response in a natural outbreak of salmon gill pox virus infection reveals new biomarkers of gill pathology and suppression of mucosal defense. Front. Immunol. 2020, 11, 2154. [CrossRef]

18. Cheng, J.X.; Xia, Y.Q.; Liu, Y.F.; Liu, P.F.; Liu, Y. Transcriptome analysis in Takifugu rubripes and Dicentrarchus labrax gills during Cryptocaryon irritans infection. J. Fish Dis. 2021, 44, 249-262. [CrossRef]

19. Marshall, W.S.; Bellamy, D. The 50 year evolution of in vitro systems to reveal salt transport functions of teleost fish gills. Comp. Biochem. Physiol. Part A 2010, 155, 275-280. [CrossRef]

20. Evans, T.G.; Kultz, D. The cellular stress response in fish exposed to salinity fluctuations. J. Exp. Zool. Part A 2020, 333, 421-435. [CrossRef] 
21. Jiang, W.; Tian, X.; Fang, Z.; Li, L.; Dong, S.; Li, H.; Zhao, K. Metabolic responses in the gills of tongue sole (Cynoglossus semilaevis) exposed to salinity stress using NMR-based metabolomics. Sci. Total Environ. 2019, 653, 465-474. [CrossRef]

22. Sun, Z.; Lou, F.; Zhang, Y.; Song, N. Gill transcriptome sequencing and de novo annotation of Acanthogobius ommaturus in response to salinity stress. Genes 2020, 11, 631. [CrossRef] [PubMed]

23. Farzadfar, F.; Doustshenas, B.; Rezaie, A.; Mousavi, S.M. Salinity induced alterations in ionic concentration of haemolymph and its effects on histopathology of gills and digestive gland in razor clam (Solen dactylus von Cosel, 1989; Bivalvia, Solenidae). Molluscan Res. 2021, 41, 92-102. [CrossRef]

24. Takata, R.; Mattioli, C.C.; Bazzoli, N.; Júnior, J.D.C.; Luz, R.K. The effects of salinity on growth, gill tissue and muscle cellularity in Lophiosilurus alexandri juvenile, a neotropical freshwater catfish. Aquac. Res. 2021, 52, 4064-4075. [CrossRef]

25. Cao, Q.; Wang, H.; Fan, C.; Sun, Y.; Li, J.; Cheng, J.; Chu, P.; Yin, S. Environmental salinity influences the branchial expression of TCR pathway related genes based on transcriptome of a catadromous fish. Comp. Biochem. Physiol. Part D 2021, $38,100815$. [CrossRef] [PubMed]

26. Cao, Q.; Li, J.; Sun, Y.; Geng, D.; Chu, P.; Wang, H.; Yin, S. Time-course studies of osmoregulatory responses in different salinities for the marbled eel (Anguilla marmorata). Aquaculture 2021, 540, 736699. [CrossRef]

27. Zhang, X.; Wen, H.; Wang, H.; Ren, Y.; Zhao, J.; Li, Y. RNA-Seq analysis of salinity stress-responsive transcriptome in the liver of spotted sea bass (Lateolabrax maculatus). PLoS ONE 2017, 12, e0173238. [CrossRef] [PubMed]

28. Si, Y.; Wen, H.; Li, Y.; He, F.; Li, J.; Li, S.; He, H. Liver transcriptome analysis reveals extensive transcriptional plasticity during acclimation to low salinity in Cynoglossus semilaevis. BMC Genom. 2018, 19, 464. [CrossRef]

29. El-Leithy, A.A.A.; Hemeda, S.A.; El Naby, W.; El Nahas, A.F.; Hassan, S.A.H.; Awad, S.T.; El-Deeb, S.I.; Helmy, Z.A. Optimum salinity for nile tilapia (Oreochromis niloticus) growth and mRNA transcripts of ion-regulation, inflammatory, stress- and immunerelated genes. Fish Physiol. Biochem. 2019, 45, 1217-1232. [CrossRef] [PubMed]

30. Li, J.; Xue, L.; Cao, M.; Zhang, Y.; Wang, Y.; Xu, S.; Zheng, B.; Lou, Z. Gill transcriptomes reveal expression changes of genes related with immune and ion transport under salinity stress in silvery pomfret (Pampus argenteus). Fish Physiol. Biochem. 2020, 46, 1255-1277. [CrossRef]

31. Cao, D.; Li, J.; Huang, B.; Zhang, J.; Pan, C.; Huang, J.; Zhou, H.; Ma, Q.; Chen, G.; Wang, Z. RNA-seq analysis reveals divergent adaptive response to hyper- and hypo-salinity in cobia, Rachycentron canadum. Fish Physiol. Biochem. 2020, 46, 1713-1727. [CrossRef] [PubMed]

32. Kim, S.H.; Thu, B.J.; Skall, H.F.; Vendramin, N.; Evensen, O. A single amino acid mutation (I1012F) of the RNA polymerase of marine viral hemorrhagic septicemia virus changes in vitro virulence to rainbow trout gill epithelial cells. J. Virol. 2014, 88 , 7189-7198. [CrossRef] [PubMed]

33. Deane, E.E.; Woo, N.Y. Tissue distribution, effects of salinity acclimation, and ontogeny of aquaporin 3 in the marine teleost, silver sea bream (Sparus sarba). Mar. Biotechnol. 2006, 8, 663-671. [CrossRef] [PubMed]

34. Watanabe, S.; Kaneko, T.; Aida, K. Aquaporin-3 expressed in the basolateral membrane of gill chloride cells in Mozambique tilapia Oreochromis mossambicus adapted to freshwater and seawater. J. Exp. Biol. 2005, 208, 2673-2682. [CrossRef] [PubMed]

35. Fiol, D.F.; Kultz, D. Osmotic stress sensing and signaling in fishes. FEBS J. 2007, 274, 5790-5798. [CrossRef] [PubMed]

36. Wichmann, L.; Althaus, M. Evolution of epithelial sodium channels: Current concepts and hypotheses. Am. J. Physiol. Regul. Integr. Comp. Physiol. 2020, 319, R387-R400. [CrossRef] [PubMed]

37. Tang, C.H.; Hwang, L.Y.; Shen, I.D.; Chiu, Y.H.; Lee, T.H. Immunolocalization of chloride transporters to gill epithelia of euryhaline teleosts with opposite salinity-induced $\mathrm{Na}^{+} / \mathrm{K}^{+}$-ATPase responses. Fish Physiol. Biochem. 2011, 37, 709-724. [CrossRef] [PubMed]

38. Lee, S.Y.; Lee, H.J.; Kim, Y.K. Comparative transcriptome profiling of selected osmotic regulatory proteins in the gill during seawater acclimation of chum salmon (Oncorhynchus keta) fry. Sci. Rep. 2020, 10, 1987. [CrossRef] [PubMed]

39. Kang, W.; Zhang, M.; Wang, Q.; Gu, D.; Huang, Z.; Wang, H.; Xiang, Y.; Xia, Q.; Cui, Z.; Jin, X. The SLC family are candidate diagnostic and prognostic biomarkers in clear cell renal cell carcinoma. Biomed. Res. Int. 2020, 2020, 1932948. [PubMed]

40. Cutler, C.P.; Murray, D.; Ojo, T.; Harmon, S.; MacIver, B.; Cramb, G.; Zeidel, M.L. Aquaporin (AQP) channels in the spiny dogfish, Squalus acanthias I: Characterization of AQP3 and AQP15 function and expression, and localization of the proteins in gill and spiral valve intestine. Comp. Biochem. Physiol. Part B 2021, 258, 110702. [CrossRef]

41. Hou, Z.-S.; Wen, H.-S. Neuropeptide Y and melanocortin receptors in fish: Regulators of energy homeostasis. Mar. Life Sci. Technol. 2021, 4, 42-51. [CrossRef]

42. Shang, X.; Ma, A.; Wang, X.; Xia, D.; Zhuang, J. Isolation, characterization and expression analysis of TRPV4 in half-smooth tongue sole Cynoglossus semilaevis. J. Oceanol. Limnol. 2020, 38, 294-305. [CrossRef]

43. Talbot, A.; Gargan, L.; Moran, G.; Prudent, L.; O'Connor, I.; Mirimin, L.; Carlsson, J.; MacCarthy, E. Investigation of the transcriptomic response in Atlantic salmon (Salmo salar) gill exposed to Paramoeba perurans during early onset of disease. Sci. Rep. 2021, 11, 20682. [CrossRef] [PubMed]

44. Fakriadis, I.; Sigelaki, I.; Papadaki, M.; Papandroulakis, N.; Raftopoulos, A.; Tsakoniti, K.; Mylonas, C.C. Control of reproduction of greater amberjack Seriola dumerili reared in aquaculture facilities. Aquaculture 2020, 519, 734880. [CrossRef]

45. Yokoyama, S.; Ishikawa, M.; Koshio, S. Dietary bovine lactoferrin enhances defense factors on body surface and anti-parasitic effects against Neobenedenia girellae infection, and mitigates low-salinity stress in amberjack (Seriola dumerili) juveniles. Aquaculture 2019, 504, 52-58. [CrossRef] 
46. Navarro-Guillén, C.; Conceição, L.E.C.; Pinto, W.; Siguero, I.; Urrutia, P.; Moyano, F.J.; Yúfera, M. Fast growing greater amberjack post-larvae require a high energy-high protein weaning diet. Aquaculture 2019, 499, 195-202. [CrossRef]

47. Chen, C.; Ji, R.; Huang, J.; He, H.; Liao, Z. The relationship between the salinity and the embryonic, early larval development in Seriola dumerili. J. Shanghai Ocean Univ. 1997, 6, 1.

48. Azodi, M.; Bahabadi, M.N.; Ghasemi, A.; Morshedi, V.; Mozanzadeh, M.T.; Shahraki, R.; Khademzadeh, O.; Hamedi, S.; Avizhgan, S. Effects of salinity on gills' chloride cells, stress indices, and gene expression of Asian seabass (Lates calcarifer, Bloch, 1790). Fish Physiol. Biochem. 2021, 47, 2027-2039. [CrossRef] [PubMed]

49. Lin, X.; Zhou, D.; Zhang, X.; Li, G.; Zhang, Y.; Huang, C.; Zhang, Z.; Tian, C. A First Insight into the Gonad Transcriptome of Hong Kong Catfish (Clarias fuscus). Animals 2021, 11, 1131. [CrossRef]

50. Araki, K.; Aokic, J.-Y.; Kawase, J.; Hamada, K.; Ozaki, A.; Fujimoto, H.; Yamamoto, I.; Usuki, H. Whole genome sequencing of greater amberjack (Seriola dumerili) for SNP identification on aligned scaffolds and genome structural variation analysis using parallel resequencing. Int. J. Genom. 2018, 2018, 7984292. [CrossRef]

51. Shi, H.; Ru, X.; Mustapha, U.F.; Jiang, D.; Huang, Y.; Pan, S.; Zhu, C.; Li, G. Characterization, expression, and regulatory effects of nrOb1a and nrOb1b in spotted scat (Scatophagus argus). Comp. Biochem. Physiol. Part B 2021, 256, 110644. [CrossRef] [PubMed]

52. Zupa, R.; Rodríguez, C.; Mylonas, C.C.; Rosenfeld, H.; Fakriadis, I.; Papadaki, M.; Perez, J.A.; Pousis, C.; Basilone, G.; Corriero, A Comparative study of reproductive development in wild and captive-reared greater amberjack Seriola dumerili (Risso, 1810). PLoS ONE 2017, 12, e0169645.

53. Pousis, C.; Mylonas, C.C.; De Virgilio, C.; Santamaria, N.; Passantino, L.; Zupa, R.; Papadaki, M.; Fakriadis, I.; Ferreri, R.; Corriero, A. The observed oogenesis impairment in greater amberjack Seriola dumerili (Risso, 1810) reared in captivity is not related to aninsufficient liver transcription or oocyte uptake of vitellogenin. Aquac. Res. 2017, 49, 1-10.

54. Pousis, C.; Rodríguez, C.; De Ruvo, P.; De Virgilio, C.; Pérez, J.A.; Mylonas, C.C.; Zupa, R.; Passantino, L.; Santamaria, N.; Valentini, L.; et al. Vitellogenin receptor and fatty acid profiles of individual lipid classes of oocytes from wild and captive-reared greater amberjack (Seriola dumerili) during the reproductive cycle. Theriogenology 2019, 140, 73-83. [CrossRef] [PubMed]

55. Nie, X.; Zhang, C.; Jiang, C.; Li, S.; Hong, W.; Chen, S.; Zhang, Y. Characterizing transcriptome changes in gill tissue of turbot (Scophthalmus maximus) for waterless preservation. Aquaculture 2020, 518, 734830. [CrossRef]

56. Kelly, S.P.; Wood, C.M. Cortisol stimulates calcium transport across cultured gill epithelia from freshwater rainbow trout. In Vitro Cell. Dev. Biol. Anim. 2008, 44, 96-104. [CrossRef]

57. Mankiewicz, J.L.; Deck, C.A.; Taylor, J.D.; Douros, J.D.; Borski, R.J. Epinephrine and glucose regulation of leptin synthesis and secretion in a teleost fish, the tilapia (Oreochromis mossambicus). Gen. Comp. Endocrinol. 2021, 302, 113669. [CrossRef]

58. Sandhu, N.; McGeer, J.C.; Vijayan, M.M. Exposure to environmental levels of waterborne cadmium impacts corticosteroidogenic and metabolic capacities, and compromises secondary stressor performance in rainbow trout. Aquat. Toxicol. 2014, 146, 20-27. [CrossRef]

59. Hartill, V.L.; Tysoe, C.; Manning, N.; Dobbie, A.; Santra, S.; Walter, J.; Caswell, R.; Koster, J.; Waterham, H.; Hobson, E. An unusual phenotype of X-linked developmental delay and extreme behavioral difficulties associated with a mutation in the EBP gene. Am. J. Med. Genet. Part A 2014, 164, 907-914. [CrossRef]

60. Juhl, A.D.; Heegaard, C.W.; Werner, S.; Schneider, G.; Krishnan, K.; Covey, D.F.; Wustner, D. Quantitative imaging of membrane contact sites for sterol transfer between endo-lysosomes and mitochondria in living cells. Sci. Rep. 2021, 11, 8927. [CrossRef]

61. Yang, F.; Kou, J.; Liu, Z.; Li, W.; Du, W. MYC Enhances cholesterol biosynthesis and supports cell proliferation through SQLE. Front. Cell Dev. Biol. 2021, 9, 655889. [CrossRef] [PubMed]

62. Furtado, L.V.; Kelley, R.I.; Opitz, J.M. Disorders of sterol biosynthesis. Transl. Sci. Rare Dis. 2016, 1, 145-182. [CrossRef]

63. Liu, Y.; Li, E.; Xu, C.; Su, Y.; Qin, J.G.; Chen, L.; Wang, X. Brain transcriptome profiling analysis of nile tilapia (Oreochromis niloticus) under long-term hypersaline stress. Front. Physiol. 2018, 9, 219. [CrossRef] [PubMed]

64. Bai, W.; Zhang, C.; Chen, H. Transcriptomic analysis of Momordica charantia polysaccharide on streptozotocin-induced diabetic rats. Gene 2018, 675, 208-216. [CrossRef] [PubMed]

65. Xin, Y.; Li, C.; Guo, Y.; Xiao, R.; Zhang, H.; Zhou, G. RNA-Seq analysis reveals a negative role of MSMO1 with a synergized NSDHL expression during adipogenesis of 3T3-L1. Biosci. Biotechnol. Biochem. 2019, 83, 641-652. [CrossRef] [PubMed]

66. Chen, M.; Zhao, Y.; Yang, X.; Zhao, Y.; Liu, Q.; Liu, Y.; Hou, Y.; Sun, H.; Jin, W. NSDHL promotes triple-negative breast cancer metastasis through the TGFbeta signaling pathway and cholesterol biosynthesis. Breast Cancer Res. Treat. 2021, 187, 349-362 [CrossRef]

67. Bauer, A.; De Lucia, M.; Jagannathan, V.; Mezzalira, G.; Casal, M.L.; Welle, M.M.; Leeb, T. A large deletion in the NSDHL gene in labrador retrievers with a congenital cornification disorder. G3 Bethesda 2017, 7, 3115-3121. [CrossRef]

68. Hlusko, L.J.; Carlson, J.P.; Chaplin, G.; Elias, S.A.; Hoffecker, J.F.; Huffman, M.; Jablonski, N.G.; Monson, T.A.; O’Rourke, D.H.; Pilloud, M.A.; et al. Environmental selection during the last ice age on the mother-to-infant transmission of vitamin D and fatty acids through breast milk. Proc. Natl. Acad. Sci. USA 2018, 115, E4426-E4432. [CrossRef]

69. Wang, B.; Liang, Y.; Chai, X.; Chen, S.; Ye, Z.; Li, R.; Li, X.; Kong, G.; Li, Y.; Zhang, X.; et al. Ectodysplasin A receptor (EDAR) promotes colorectal cancer cell proliferation via regulation of the Wnt/beta-catenin signaling pathway. Exp. Cell Res. 2020, 395, 112170. [CrossRef] [PubMed] 
70. Zhang, H.; Kong, X.; Ren, J.; Yuan, S.; Liu, C.; Hou, Y.; Liu, Y.; Meng, L.; Zhang, G.; Du, Q.; et al. A novel EDAR missense mutation identified by whole-exome sequencing with non-syndromic tooth agenesis in a Chinese family. Mol. Genet. Genom. Med. 2021, 9, e1684. [CrossRef]

71. Li, M.; Bai, Y.T.; Han, K.; Li, X.D.; Meng, J. Knockdown of ectodysplasin-A receptor-associated adaptor protein exerts a tumor-suppressive effect in tongue squamous cell carcinoma cells. Exp. Ther. Med. 2020, 19, 3337-3347. [CrossRef] [PubMed]

72. Hauner, H.; Link, D.; Wabitsch, M.; Brinkmann, U.; Keuper, M.; Skurk, T.; Finck, A.; Laumen, H.; Fischer-Posovszky, P.; Tiller, G. Effects of TWEAK (TNF Superfamily Member 12) on differentiation, metabolism, and secretory function of human primary preadipocytes and adipocytes. Endocrinology 2009, 150, 5373-5383.

73. Nguyen, T.V.; Jung, H.; Nguyen, T.M.; Hurwood, D.; Mather, P. Evaluation of potential candidate genes involved in salinity tolerance in striped catfish (Pangasianodon hypophthalmus) using an RNA-Seq approach. Mar. Genom. 2016, 25, 75-88. [CrossRef] [PubMed]

74. Mailloux, R.J.; Ayre, D.C.; Christian, S.L. Induction of mitochondrial reactive oxygen species production by GSH mediated S-glutathionylation of 2-oxoglutarate dehydrogenase. Redox Biol. 2016, 8, 285-297. [CrossRef] [PubMed]

75. Mu, Y.; Li, W.; Wei, Z.; He, L.; Zhang, W.; Chen, X. Transcriptome analysis reveals molecular strategies in gills and heart of large yellow croaker (Larimichthys crocea) under hypoxia stress. Fish Shellfish Immunol. 2020, 104, 304-313. [CrossRef] [PubMed]

76. Shmukler, B.E.; Reimold, F.R.; Heneghan, J.F.; Chen, C.; Zhao, T.; Paw, B.H.; Alper, S.L. Molecular cloning and functional characterization of zebrafish Slc4a3/Ae3 anion exchanger. Pflug. Arch. Eur. J. Physiol. 2014, 466, 1605-1618. [CrossRef]

77. Liu, S.T.; Horng, J.L.; Chen, P.Y.; Hwang, P.P.; Lin, L.Y. Salt secretion is linked to acid-base regulation of ionocytes in seawateracclimated medaka: New insights into the salt-secreting mechanism. Sci. Rep. 2016, 6, 31433. [CrossRef]

78. Madsen, S.S.; Jensen, L.N.; Tipsmark, C.K.; Kiilerich, P.; Borski, R.J. Differential regulation of cystic fibrosis transmembrane conductance regulator and $\mathrm{Na}^{+}, \mathrm{K}^{+}$-ATPase in gills of striped bass, Morone saxatilis: Effect of salinity and hormones. J. Endocrinol. 2007, 192, 249-260. [CrossRef]

79. Scott, G.R.; Schulte, P.M. Intraspecific variation in gene expression after seawater transfer in gills of the euryhaline killifish Fundulus heteroclitus. Comp. Biochem. Physiol. Part A 2005, 141, 176-182. [CrossRef]

80. Singer, T.D.; Clements, K.M.; Semple, J.W.; Schulte, P.M.; Bystriansky, J.S.; Finstad, B.; Fleming, I.A.; McKinley, R.S. Seawater tolerance and gene expression in two strains of Atlantic salmon smolts. Can. J. Fish. Aquat. Sci. 2002, 59, 125-135. [CrossRef]

81. Ma, Q.; Liu, X.; Li, A.; Liu, S.; Zhuang, Z. Effects of osmotic stress on the expression profiling of aquaporin genes in the roughskin sculpin (Trachidermus fasciatus). Acta Oceanol. Sin. 2020, 39, 19-25. [CrossRef]

82. Cutler, C.P.; Maciver, B.; Cramb, G.; Zeidel, M. Aquaporin 4 is a ubiquitously expressed isoform in the dogfish (Squalus acanthias) shark. Front. Physiol. 2011, 2, 107. [CrossRef] [PubMed]

83. Roy, J.; Terrier, F.; Marchand, M.; Herman, A.; Heraud, C.; Surget, A.; Lanuque, A.; Sandres, F.; Marandel, L. Effects of low stocking densities on zootechnical parameters and physiological responses of rainbow trout (Oncorhynchus mykiss) juveniles. Biology 2021, 10, 1040. [CrossRef] [PubMed]

84. Zhang, S.; Li, C.Z.; Yang, Q.H.; Dong, X.H.; Chi, S.Y.; Liu, H.Y.; Shi, L.L.; Tan, B.P. Molecular cloning, characterization and expression analysis of Wnt4, Wnt5, Wnt6, Wnt7, Wnt10 and Wnt16 from Litopenaeus vannamei. Fish Shellfish Immunol. 2016, 54, 445-455. [CrossRef] [PubMed]

85. Weng, S.; You, F.; Fan, Z.; Wang, L.; Wu, Z.; Zou, Y. Molecular cloning and sexually dimorphic expression of wnt4 in olive flounder (Paralichthys olivaceus). Fish Physiol. Biochem. 2016, 42, 1167-1176. [CrossRef] [PubMed]

86. Schmitz, M.; Baekelandt, S.; Bequet, S.; Kestemont, P. Chronic hyperosmotic stress inhibits renal Toll-Like Receptors expression in striped catfish (Pangasianodon hypophthalmus, Sauvage) exposed or not to bacterial infection. Dev. Comp. Immunol. 2017, 73, 139-143. [CrossRef]

87. Liu, F.; Su, B.; Fu, Q.; Shang, M.; Gao, C.; Tan, F.; Li, C. Identification, characterization and expression analysis of TLR5 in the mucosal tissues of turbot (Scophthalmus maximus L.) following bacterial challenge. Fish Shellfish Immunol. 2017, 68, 272-279. [CrossRef]

88. Yang, J.; Yan, H. TLR5: Beyond the recognition of flagellin. Cell. Mol. Immunol. 2017, 14, 1017-1019. [CrossRef]

89. Luo, S.; Deng, X.; Liu, Q.; Pan, Z.; Zhao, Z.; Zhou, L.; Luo, X. Emodin ameliorates ulcerative colitis by the flagellin-TLR5 dependent pathway in mice. Int. Immunopharmacol. 2018, 59, 269-275. [CrossRef] 